\title{
Micro-continuum modelling of injection strategies for microbially induced carbonate precipitation
}

\author{
James M. Minto ${ }^{1 *}$, Grainne El Mountassir ${ }^{1}$, and Rebecca J. Lunn ${ }^{1}$ \\ ${ }^{1}$ University of Strathclyde, Department of Civil \& Environmental Engineering, UK
}

\begin{abstract}
Microbially induced carbonate precipitation is a promising technique for ground improvement. In order for MICP to progress from a lab-scale process to a commercially viable alternative ground improvement option, a combination of field-trials and field-scale modelling of the process is required. We present the results of a field-scale model in which differing injection strategies are evaluated and find that longer treatment times make more efficient use of reagents, but may come with higher operational costs, and that utilising multiple strains of bacteria with different reaction kinetics and transport properties may improve efficiency.
\end{abstract}

\section{Introduction to MICP}

Microbially Induced Carbonate Precipitation (MICP) is a naturally occurring process in which the by-products of bacteria growth and respiration create ideal chemical conditions for calcium carbonate to form as a mineral. We use the well-studied urea hydrolysis pathway (overall pathway shown in equations $1 \& 2$ ) to create calcium carbonate in-situ as an alternative grout with novel engineering properties. The inputs for this process are urea (a common fertiliser), a calcium source (e.g. calcium chloride), and ureolytically active bacteria, most commonly Sporosarcina pasteurii [1].

$$
\begin{aligned}
& \text { urea }+ \text { water }+ \text { calcium } \underset{\text { bacteria }}{\longrightarrow} \text { calcite }+ \text { ammonium (1) } \\
& \mathrm{CO}\left(\mathrm{NH}_{2}\right)_{2}+2 \mathrm{H}_{2} \mathrm{O}+\mathrm{Ca}^{2+} \underset{\text { urease }}{\longrightarrow} \mathrm{CaCO}_{3}+2 \mathrm{NH}_{4}^{+}
\end{aligned}
$$

The advantages of using MICP over traditional cement and chemical grouts are 1) the input solutions have a near water-like viscosity meaning low injection pressure equipment is required and MICP can be used for nearsurface ground improvement without risk of ground heave, 2) MICP could be more environmentally friendly with a potentially lower carbon footprint than cement, and less toxic than chemical grouts, and 3) it is possible to create impermeable barriers or to optionally increase strength without significantly reducing porosity and drainage.

MICP appears to be a promising technique for reducing water flow in radioactive waste geological disposal facilities [2], for reducing leakage from oil, gas and carbon capture \& storage wells [3,4], and as a ground improvement technique [5], particularly where nearsurface treatment is required or where existing soil cannot be removed from site.

MICP has been well studied in the lab. From these small-scale experiments we have learned, for example, how improvement in soil strength is related to $\mathrm{CaCO}_{3}$ content (Fig. 1). However, only a limited number of fieldscale trials have been carried out, each in quite different environments with different objectives and, consequently, differing treatment strategies [4,6-8].

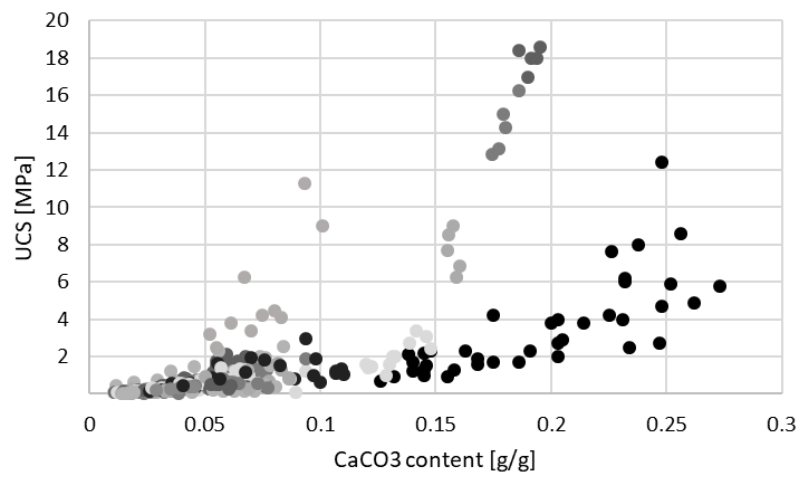

Fig. 1. Relationship between $\mathrm{CaCO}_{3}$ content and unconfined compressive strength, taken from the literature [9-20].

In order for MICP to progress from a lab-scale process to a commercially viable alternative ground treatment option, more field trials are required. To maximise the effectiveness of these future field trials we must first narrow down the extensive range of variables (relating to environmental conditions, what we inject, and how we inject it) into a handful of the most promising injection strategies.

To do this, we have turned to numerical modelling of the MICP process with the aim of identifying strategies that make the most efficient use of reagents, make the most efficient use of time, and produce the most uniform and controllable treatment. Specifically, we model different urea/calcium concentrations, different reaction times, and three different types of ureolytic bacteria.

\footnotetext{
*Corresponding author: james.minto@strath.ac.uk
} 


\section{Model description}

The model has been implemented in the computational fluid dynamics software OpenFOAM. Fluid flow is based on the single-phase (fully saturated) Navier-Stokes equations with an additional term that accounts for resistance in porous media. In this way, the model can simulate fluid flow through fractures in rock, and in soil at both pore-scale and continuum-scale, hence the name micro-continuum modelling.

Reactive transport of bacteria, urea, calcium, and the ammonium and carbonate by-products are included. Bacteria transport is a function of soil type, bacteria characteristics (size, stickiness), and velocity with less bacterial attachment in areas of high velocity. When urea (injected after the bacteria) reaches bacterial cells which have attached within the porous media, the urea is hydrolysed following the first-order Michaelis-Menten kinetics producing ammonium and carbonate. When calcium and carbonate mix, they precipitate as $\mathrm{CaCO}_{3}$ on the first surface encountered.

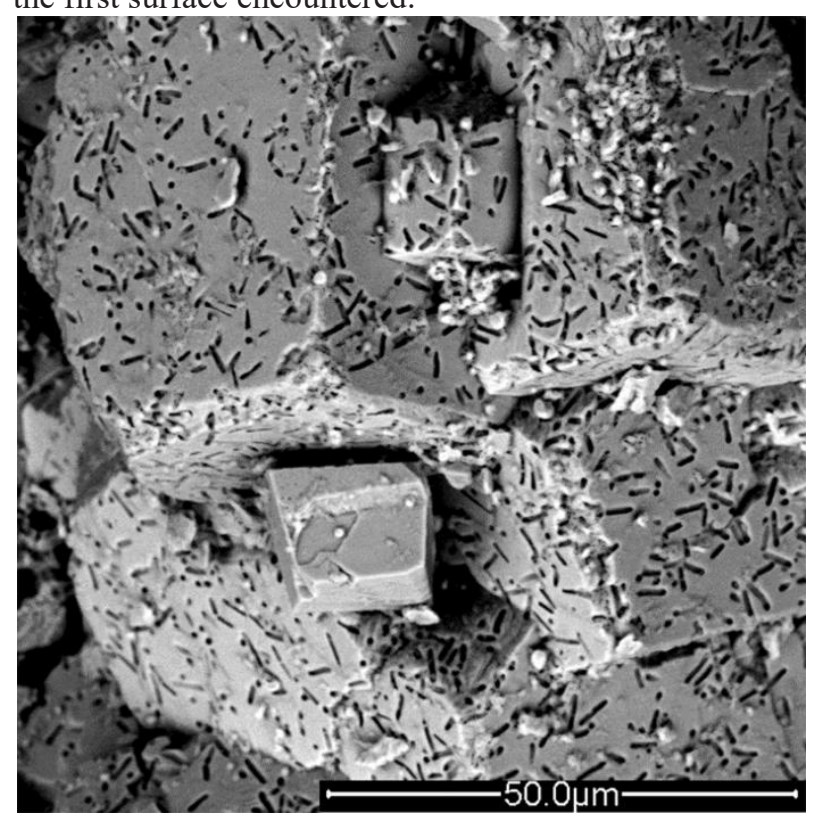

Fig. 2. Scanning electron microscope image of microbially induced $\mathrm{CaCO}_{3}$. The rod shaped indentations are the remnants of bacterial cells that became encapsulated in the growing $\mathrm{CaCO}_{3}$ crystals.

The precipitated $\mathrm{CaCO}_{3}$ is non-transportable and occupies some of the pore space resulting in a lower permeability and a redirection of flow in subsequent injections of reagents. The $\mathrm{CaCO}_{3}$ also encapsulates attached bacteria, cutting them off from the urea and ending the reaction (Fig. 2). For this reason, multiple cycles of bacteria followed by urea/calcium cementing solution are injected until sufficient $\mathrm{CaCO}_{3}$ has been precipitated for effective ground improvement.

The model was calibrated with experimental results from batch experiments [21] in which urea hydrolysis over time was measured along with the final mass of $\mathrm{CaCO}_{3}$ produced.

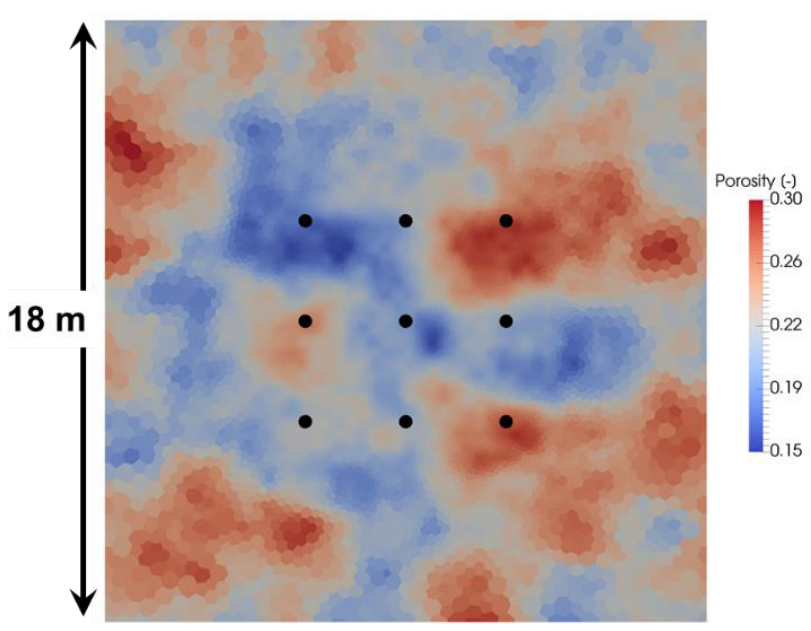

Fig. 3. Field-scale model with location of wells and initial porosity distribution.

Our field-scale test model consisted of a nine well array with $3 \mathrm{~m}$ well spacing in which reagents are injected through the outer eight wells, and extracted from the central well. Initial conditions are a random porosity distribution (Fig. 3).

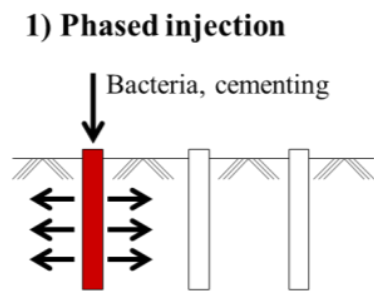

2) Simultaneous
injection

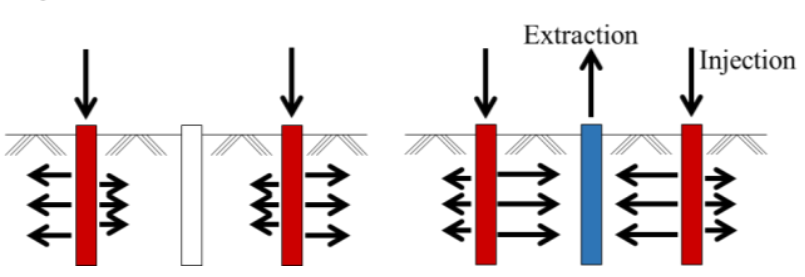

Fig. 4. Example of potential treatment strategies that can be modelled.

Model boundary conditions are flexible enough to allow simultaneous injection and extraction from multiple wells (Fig. 4), as well as monitoring the cumulative concentrations of reagents entering and exiting the model through the wells and the four side boundaries. The total mass of $\mathrm{CaCO}_{3}$ precipitating within an area of interest extending $3 \mathrm{~m}$ around each well is also monitored.

Variables investigated were 1) the concentration of urea and calcium in the cementing solution (with a low concentration of $0.1 \mathrm{M}$ and a high concentration of 0.4 $\mathrm{M}), 2$ ) the length of time between cycles (between 2 and 22 hours) and 3 ) the type of ureaolytic bacteria.

The standard bacteria was $S$. pasteurii with high ureaolytic activity (10mM urea/min/OD) and high Michaelis-Menten half saturation constant (301 mM).

The second has the properties of a bacterium isolated from soil by Graddy et al. [22] designated LS57 with a lower activity of $5.6 \mathrm{mM}$ urea/min/OD, but also a lower 
half saturation constant of $64 \mathrm{mM}$. The lower half saturation constant of LS57 means that the reaction rate does not slow down as much at low urea concentrations (see Fig. 5).

The third bacterium was a hypothetical strain with urea hydrolysis properties similar to LS57, but with different physical cell properties (i.e. smaller cells that produce less extracellular polymeric substances/biofilm) hence can be transported further before attaching within the porous media.

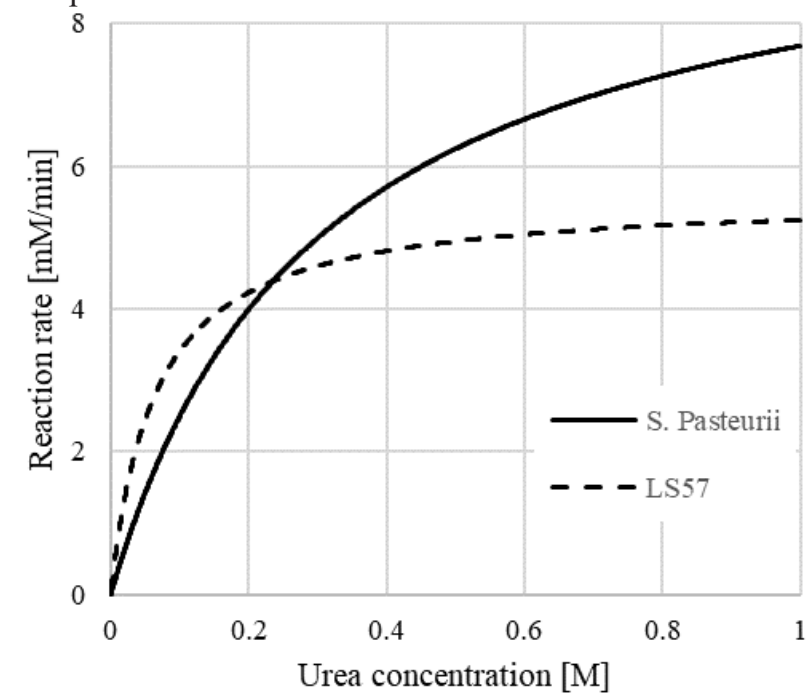

Fig. 5. Urea hydrolysis kinetics for the two bacterial strains.

\section{Model results}

All field-scale models were run with boundary conditions of fixed flow rate inlet, constant pressure outlets.

The models indicated that increasing the reaction period between treatment cycles resulted in more $\mathrm{CaCO}_{3}$ precipitating and increased efficiency (where efficiency was measured as the amount of urea converted to $\mathrm{CaCO}_{3}$ ), but this came at the expense of longer treatment times (see Table 1). Decreasing the cementing solution concentration increased efficiency, but decreased the total mass of $\mathrm{CaCO}_{3}$.

Table 1. Field-scale simulation results for reaction duration and cementing solution concentration for S.pasteurii. Mass of

$\mathrm{CaCO}_{3}$ measured at the end of 10 injection cycles.

\begin{tabular}{|c|c|c|c|c|c|}
\hline Run & $\begin{array}{c}\text { Reaction } \\
\text { period } \\
{[\mathrm{hrs}]}\end{array}$ & $\begin{array}{c}\text { Urea/ } \\
\mathrm{Ca}[\mathrm{M}]\end{array}$ & $\begin{array}{c}\text { Treatment } \\
\text { time } \\
{[\text { days] }}\end{array}$ & $\begin{array}{c}\mathrm{CaCO}_{3} \\
\text { mass } \\
{[\mathrm{kg}]}\end{array}$ & $\begin{array}{c}\text { Urea } \\
\text { utilization } \\
\text { efficiency } \\
{[\%]}\end{array}$ \\
\hline 1 & $\mathbf{4}$ & $0.4 / 0.4$ & 2.65 & 2,887 & $28.0 \%$ \\
\hline 2 & $\mathbf{1 2}$ & $0.4 / 0.4$ & 5.98 & 3,721 & $36.1 \%$ \\
\hline 3 & 2 & $0.4 / 0.4$ & 1.81 & 2,460 & $23.9 \%$ \\
\hline 4 & 4 & $\mathbf{0 . 2 / 0 . 2}$ & 2.65 & 2,303 & $44.7 \%$ \\
\hline 5 & 12 & $\mathbf{0 . 2 / 0 . 2}$ & 5.98 & 2,762 & $53.7 \%$ \\
\hline
\end{tabular}

The models also indicated that substituting some or all of the $S$. pasteurii with the LS57 bacterium resulted in more $\mathrm{CaCO}_{3}$ precipitating and a greater efficiency (Table 2 ), but only where the initial urea concentration was significantly lower than the Michaelis-Menten half saturation constant of $0.3 \mathrm{M}$ for $S$. pasteurii (see solid lines in Fig. 6 where urea concentration was $0.1 \mathrm{M}$ ). In simulations where the urea concentration was $0.4 \mathrm{M}$ (dashed lines in Fig. 6), replacing S. pasteurii with LS57 marginally reduced the amount of $\mathrm{CaCO}_{3}$ that precipitated over the first 12 hours of the cycle.

A special case is Run 17 where the urea concentration was $0.4 \mathrm{M}$, but LS57 was assumed to have different physical properties resulting in lower attachment. This case resulted in the greatest amount of $\mathrm{CaCO}_{3}$ and a significantly higher efficiency. The impact of altering bacterial attachment properties can be seen in Fig. 7 .

Table 2. Field-scale simulation results for different bacterial strains. Mass of $\mathrm{CaCO}_{3}$ measured at the end of a single $24 \mathrm{hr}$ injection cycle.

\begin{tabular}{|c|c|c|c|c|}
\hline Run & $\begin{array}{c}\text { Urea/ } \\
\mathrm{Ca}[\mathrm{M}]\end{array}$ & $\begin{array}{c}\text { Bacterial } \\
\text { composition }\end{array}$ & $\begin{array}{c}\mathrm{CaCO}_{3} \\
\text { mass } \\
{[\mathrm{kg}]}\end{array}$ & $\begin{array}{c}\text { Urea } \\
\text { utilization } \\
\text { efficiency } \\
{[\%]}\end{array}$ \\
\hline 6 & $0.1 / 0.1$ & S.pasteurii & 194 & $75.3 \%$ \\
\hline 7 & $0.2 / 0.2$ & S.pasteurii & 333 & $64.6 \%$ \\
\hline 8 & $0.4 / 0.4$ & S.pasteurii & 485 & $47.1 \%$ \\
\hline 9 & $0.1 / 0.1$ & S.pasteurii/LS57 & 206 & $80.1 \%$ \\
\hline 10 & $0.2 / 0.2$ & S.pasteurii/LS57 & 343 & $66.6 \%$ \\
\hline 11 & $0.4 / 0.4$ & S.pasteurii/LS57 & 489 & $47.5 \%$ \\
\hline 12 & $0.1 / 0.1$ & LS57 & 216 & $83.9 \%$ \\
\hline 13 & $0.2 / 0.2$ & LS57 & 351 & $68.2 \%$ \\
\hline 14 & $0.4 / 0.4$ & LS57 & 492 & $47.8 \%$ \\
\hline 15 & $0.1 / 0.1$ & $\begin{array}{c}\text { S.pasteurii/ low } \\
\text { attach LS57 }\end{array}$ & 240 & $93.0 \%$ \\
\hline 16 & $0.2 / 0.2$ & $\begin{array}{c}\text { S.pasteurii/ low } \\
\text { attach LS57 }\end{array}$ & 430 & $83.5 \%$ \\
\hline 17 & $0.4 / 0.4$ & $\begin{array}{c}\text { S.pasteurii/ low } \\
\text { attach LS57 }\end{array}$ & 634 & $61.6 \%$ \\
\hline
\end{tabular}

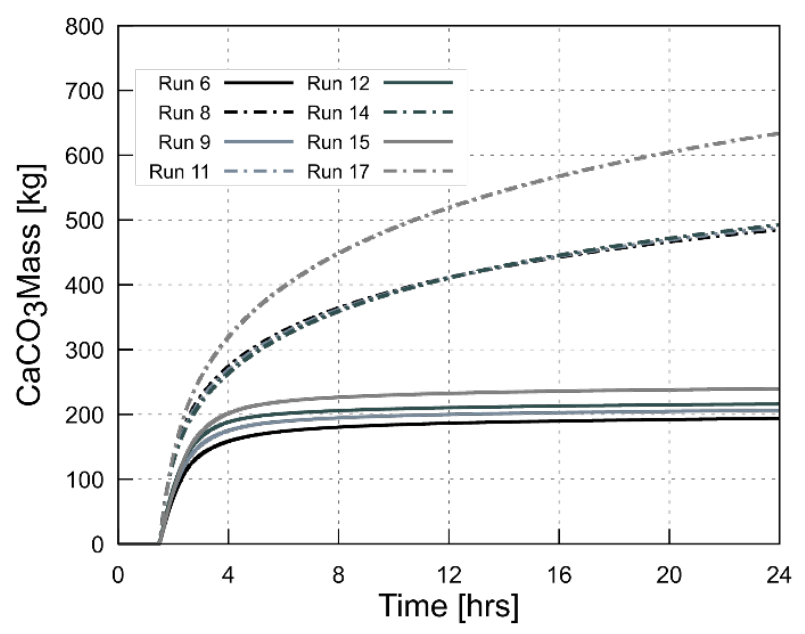

Fig. 6. Field-scale results showing total mass of $\mathrm{CaCO}_{3}$ precipitated during a single $24 \mathrm{hr}$ injection cycle for all 4 bacteria strain combinations (see Table 2) at cementing solution concentrations of $0.1 \mathrm{M}$ (solid lines) and $0.4 \mathrm{M}$ (dashed lines). 

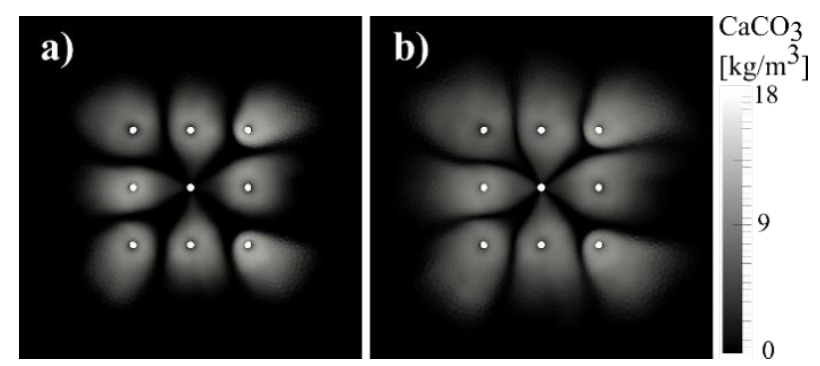

Fig. 7. Field-scale results showing $\mathrm{CaCO}_{3}$ distribution after one injection cycle with a urea concentration of $0.4 \mathrm{M}$ for a) $S$. pasteurii, and b) low attachment LS57.

\section{Discussion}

\subsection{Reaction time \& reagent concentration}

In the field-scale model we see that longer reaction periods made more efficient use of urea. However, this came with diminishing returns for two reasons: 1) most of the bacteria become encapsulated in the early part of each injection cycle hence the reaction rate drops considerably within a few hours, and 2) the Michaelis-Menten reaction kinetics mean that as urea concentration decreases, the rate of urea hydrolysis further decreases.

The most efficient strategy based on utilization of urea and bacteria would be long cementation periods (in excess of 12 hours) and low urea/ calcium concentrations (lower than $0.2 \mathrm{M}$ ) as, even under these conditions, the supply of urea and un-encapsulated bacteria were not exhausted before the next injection cycle. However, although less efficient in terms of reagents, a two-hour cementation period with a concentration of $0.4 \mathrm{M}$ produced a comparable amount of $\mathrm{CaCO}_{3}$ in approximately one third the time.

As much of the costs associated with ground improvement are due to staff time and equipment that is tied-up on site, together with heavy penalties for delays in the construction schedule, we suspect that there are situations where an engineering contractor would find it economical to optimise MICP ground improvement to minimise treatment time, rather than maximise reagents efficiency.

\subsection{Bacterial strain combinations}

S. pasteurii is the most commonly utilised bacteria for MICP due to its comparably high ureolytic activity. We find that when urea concentrations are high, $S$. pasteurii has the desirable trait of producing more $\mathrm{CaCO}_{3}$ in a shorter period of time than strains with a lower activity.

However, if maximum reagent efficiency is required, at some point urea concentration must drop below $S$. pasteurii's optimum concentration. At this point, other less active bacteria may precipitate more $\mathrm{CaCO}_{3}$ in a given period of time if, like strain LS57, they have a lower Michaelis-Menten half saturation constant that allows them to be more efficient at lower urea concentrations.

Finally, combining S. pasteurii with a hypothetical bacterium with the reaction kinetics of LS57, but with different attachment properties, produces the most $\mathrm{CaCO}_{3}$. This is because the two strains are spatially distributed in different areas: S. pasteurii attaches close to the injection wells where urea concentrations are highest, whilst LS57 attaches further away where it can make efficient use of the leftover urea that makes it to these outer edges.

Modelling shows that an approach of combining different bacteria strains with different attachment properties may make more efficient use of the urea. It has also been suggested that co-cultures of bacteria can increase $\mathrm{CaCO}_{3}$ precipitation by providing more nucleation sites $[23,24]$ or prove to be more robust across a range of environmental conditions [25]. However, these benefits would have to be weighed against the extra costs required to optimally grow, store, and transport multiple types of bacteria compared with $S$. pasteurii alone.

\section{References}

1. J.H. Yoon, K.C. Lee, N. Weiss, Y.H. Kho, K.H. Kang, Y.H. Park, Sporosarcina aquimarina sp. nov., a bacterium isolated from seawater in Korea, and transfer of Bacillus globisporus (Larkin and Stokes 1967), Bacillus psychrophilus (Nakamura 1984) and Bacillus pasteurii (Chester 1898) to the genus Sporosarcina as Sporosa, Int. J. Syst. Evol. Microbiol. 51 (2001) 1079-86. http://www.ncbi.nlm.nih.gov/pubmed/11411676.

2. J.M. Minto, E. MacLachlan, G. El Mountassir, R.J. Lunn, Rock fracture grouting with microbially induced carbonate precipitation, Water Resour. Res. 52 (2016) 8827-8844. doi:10.1002/2016WR018884.

3. A.B. Cunningham, A.J. Phillips, E. Troyer, E. Lauchnor, R. Hiebert, R. Gerlach, L. Spangler, Wellbore leakage mitigation using engineered biomineralization, Energy Procedia. 63 (2014) 4612-4619. doi:10.1016/j.egypro.2014.11.494.

4. A.J. Phillips, A.B. Cunningham, R. Gerlach, R. Hiebert, C. Hwang, B.P. Lomans, J. Westrich, C. Mantilla, J. Kirksey, R.A. Esposito, L. Spangler, Fracture Sealing with Microbially-Induced Calcium Carbonate Precipitation: A Field Study, Environ. Sci. Technol. (2016) acs.est.5b05559. doi:10.1021/acs.est.5b05559.

5. J.T. DeJong, K. Soga, S. a Banwart, W.R. Whalley, T.R. Ginn, D.C. Nelson, B.M. Mortensen, B.C. Martinez, T. Barkouki, Soil engineering in vivo: harnessing natural biogeochemical systems for sustainable, multi-functional engineering solutions, J. R. Soc. Interface. 8 (2010) 1-15. doi:10.1098/rsif.2010.0270.

6. L.A. van Paassen, M.P. Harkes, G.A. Van Zwieten, W.H. van der Zon, W.R.L. Van Der Star, M.C.M. van Loosdrecht, Scale up of BioGrout: A biological ground reinforcement method, Proc. 17th Int. Conf. Soil Mech. Geotech. Eng. Acad. Pract. Geotech. Eng. 3 (2009) 2328-2333. doi:10.3233/978-160750-031-5-2328. 
7. M.G. Gomez, B.C. Martinez, J.T. DeJong, C.E. Hunt, L.A. DeVlaming, D.W. Major, S.M. Dworatzek, Field-scale bio-cementation tests to improve sands, Proc. Inst. Civ. Eng. - Gr. Improv. 168 (2015) 1-11. doi:10.1680/grim.13.00052.

8. M.O. Cuthbert, L.A. McMillan, S. Handley-Sidhu, M.S. Riley, D.J. Tobler, V.R. Phoenix, A field and modeling study of fractured rock permeability reduction using microbially induced calcite precipitation., Environ. Sci. Technol. 47 (2013) 13637-43. doi:10.1021/es402601g.

9. A. Al Qabany, K. Soga, Effect of chemical treatment used in MICP on engineering properties of cemented soils, Géotechnique. 63 (2013) 331339. doi:10.1680/geot.SIP13.P.022.

10. L. Cheng, R. Cord-Ruwisch, M.A. Shahin, Cementation of sand soil by microbially induced calcite precipitation at various degrees of saturation, Can. Geotech. J. 50 (2013) 81-90. doi:10.1139/cgj-2012-0023.

11. L. Cheng, M.A. Shahin, D. Mujah, Influence of Key Environmental Conditions on Microbially Induced Cementation for Soil Stabilization, J. Geotech. Geoenvironmental Eng. 143 (2017) 04016083. doi:10.1061/(ASCE)GT.19435606.0001586 .

12. S. Choi, S. Wu, J. Chu, Biocementation for Sand Using an Eggshell as Calcium Source, J. Geotech. Geoenvironmental Eng. 142 (2016) 2-5. doi:10.1061/(ASCE)GT.1943-5606.0001534.

13. M.J. Cui, J.J. Zheng, R.J. Zhang, H.J. Lai, J. Zhang, Influence of cementation level on the strength behaviour of bio-cemented sand, Acta Geotech. 12 (2017) 971-986. doi:10.1007/s11440-017-0574-9.

14. M. Li, K. Wen, Y. Li, L. Zhu, Impact of Oxygen Availability on Microbially Induced Calcite Precipitation (MICP) Treatment, Geomicrobiol. J. 35 (2018) 15-22.

doi:10.1080/01490451.2017.1303553.

15. D. Li, T. Kan-liang, Z. Hui-li, W. Yu-yao, N. Kang-yi, Z. Shi-can, Experimental investigation of solidifying desert aeolian sand using microbially induced calcite precipitation, Constr. Build. Mater. 172 (2018) 251-262. doi:10.1016/j.conbuildmat.2018.03.255.

16. A. Mahawish, A. Bouazza, W.P. Gates, Effect of particle size distribution on the bio-cementation of coarse aggregates, Acta Geotech. (2017) 1-7. doi:10.1007/s11440-017-0604-7.

17. K. Rowshanbakht, M. Khamehchiyan, R.H. Sajedi, M.R. Nikudel, Effect of injected bacterial suspension volume and relative density on carbonate precipitation resulting from microbial treatment, Ecol. Eng. 89 (2016) 49-55. doi:10.1016/j.ecoleng.2016.01.010.
18. D. Terzis, L. Laloui, 3-D micro-architecture and mechanical response of soil cemented via microbial-induced calcite precipitation, Sci. Rep. 8 (2018) 1416. doi:10.1038/s41598-018-19895-w.

19. L.A. van Paassen, R. Ghose, T.J.M. Van Der Linden, W.R.L. Van Der Star, M.C.M. Loosdrecht, Quantifying Biomediated Ground Improvement by Ureolysis: Large-Scale Biogrout Experiment, J. Geotech. Geoenvironmental Eng. 136 (2010) 1721-1728. doi:10.1061/(ASCE)GT.1943-5606.0000382.

20. L. Cheng, M. Shanin, R. Cord-Ruwisch, Biocementation of sandy soil using microbially induced carbonate precipitation for marine environments, Géotechnique. 64 (2014) 10101013.

http://www.icevirtuallibrary.com/content/article/1 0.1680/geot.14.T.025.

21. E. MacLachlan, Development of a microbially induced calcite and silica bio-grout for the sealing of fine aperture fractures, University of Strathclyde, 2017.

22. C.M.R. Graddy, M.G. Gomez, L.M. Kline, S.R. Morrill, J.T. Dejong, D.C. Nelson, Diversity of Sporosarcina -like Bacterial Strains Obtained from Meter-Scale Augmented and Stimulated Biocementation Experiments, Environ. Sci. Technol. 52 (2018) 3997-4005. doi:10.1021/acs.est.7b04271.

23. C.D. Burt, M.L. Cabrera, M.J. Rothrock, D.E. Kissel, Urea Hydrolysis and Calcium Carbonate Precipitation in Gypsum-Amended Broiler Litter, J. Environ. Qual. (2018) 162-169. doi:10.2134/jeq2017.08.0337.

24. D. Gat, M. Tsesarsky, D. Shamir, Z. Ronen, Accelerated microbial-induced $\mathrm{CaCO} 3$ precipitation in a defined coculture of ureolytic and non-ureolytic bacteria, Biogeosciences. 11 (2014) 2561-2569. doi:10.5194/bg-11-25612014.

25. J. Zhang, A. Zhou, Y. Liu, B. Zhao, Y. Luan, S. Wang, X. Yue, Z. Li, Microbial network of the carbonate precipitation process induced by microbial consortia and the potential application to crack healing in concrete, Sci. Rep. 7 (2017) 110. doi:10.1038/s41598-017-15177-z. 